\title{
THE IMPLIED CONSPIRACY DOCTRINE AND DELIVERED PRICING
}

\author{
Sumner S. Kittelle* and George P. Lamb $\dagger$
}

An important weapon in the Federal Trade Commission's attack on industrywide use of delivered pricing methods has been the doctrine of implied conspiracy, more recently called the doctrine of "conscious parallelism of action."1 Other weapons have been the definition of "price" as the seller's "mill net return," denial of a seller's right to meet competitive prices "systematically"3 (or where such meeting results in injury to competition), ${ }^{4}$ and direct proof of collusion among competitors in the adoption, continued use, or alteration of a delivered pricing method. ${ }^{\mathbf{0}}$

The trend of advancement of the "conscious parallelism of action" doctrine by the Commission, with considerable recognition if not approval by reviewing courts, has now reached a crucial point. Unless the Federal Trade Commission changes

*.S.C.E. I93I, Purdue University; J.D. I936, George Washington University. Member of the District of Columbia and New York bars. Contributor to legal and business periodicals.

† B.S. I931, Purdue University; LL.B. 1935, J.D. I936, Georgetown University. Member of the District of Columbia bar. Chairman, American Bar Association Committee on Trade Associations, since 1949.

The authors gratefully acknowledge the assistance in the preparation of this article of Frazer F. Hilder of the District of Columbia bar, author of The Attack Upon Delivered Price Systems, I4 Geo. WaSH. L. REv. 397 (1946).

1 The term appears in the Federal Trade Commission's published Notice to the Staff: In Re CoMmission Policy Toward Geographic Pricing Practices, Oct. 12, I948, p. 3.

2 The Robinson-Patman bill contained such a definition of "price," but it was withdrawn by the House Judiciary Committee, 80 Cong. Rec. 8Io2, 8140, 8224 (1936). However, Walter B. Wooden, as Associate General Counsel for the Commission, tried to argue the definition back into the law by another route-namely, the argument that sellers are not merely permitted but affirmatively required to make "only due allowance" for common carrier transportation costs in arriving at delivered prices. CCH, Robinson-Patman Acr Symposium, Section on Food, Drug and Cosmetic Law of the New York Strte Bar.Ass'n 79 et seq. (1946). This means that the seller must add to his mill price only the exact amount of common carrier transportation cost, no more and no less. Some support for the "mill net return" method of measuring discrimination appears by way of dictum in the Supreme Court's opinion in Federal Trade Comm'n v. Cement Institute, 333 U. S. 683, 722, 725-726 (1948), wherein the Court stated: "The Commission held that the varying mill nets received by respondents on sales between customers in different localities constituted a 'discrimination in price between different purchasers' within the prohibition of Section 2(a) ..."; and later: "We hold that the Commission properly concluded that respondents' pricing system results in price discriminations." The Commission now says it has not necessarily espoused the "mill net" theory. Notice to THE STAFF, supra note $I$, at 5,6 . See also Dawkins, Defenses Auailable in Cases of Geographic Price Discriminations, 37 Geo. L. J. 217, 218 et seq. (1949). But its legal staff still uses the theory in its briefs in pending cases. See letter from Kittelle to William Simon, February 21, 1949, in Hearings before the Subcommittee of Senate Committee on Interstate and Foreign Commerce on S. 236, 81st Cong., Ist Sess. 325 (I949).

${ }^{3}$ Federal Trade Comm'n v. Cement Institute, 333 U. S. $683,723-724$ (I948); cf. Federal Trade Comm'n v. A. E. Staley Mfg. Co., 324 U. S. 746, 755-757 (r945).

4 Standard Oil Co. v. Federal Trade Comm'n, 173 F. 2d 210 (C. C. A. 7th 1949).

There was such evidence in both Federal Trade Comm'n v. Cement Institute, supra note 3, and Triangle Conduit \& Cable Co. v. Federal Trade Comm'n, 168 F. 2d 175 (C. C. A. 7th 1948), aff'd per curiam sub nom. Clayton Mark \& Co. v. Federal Trade Comm'n, 336 U. S. 956 (I949), popularly known as the Rigid Steel Conduit case. 
its policy, or the courts reject the Commission's theories, or Congress takes remedial action, vigorous, informed, geographical competition will no longer be able to exist except under the shadow of threatened litigation. ${ }^{6}$

It is the purpose of this article to discuss the development, use, and potential future availability to the Commission (and the Commission's trial attorneys) of the doctrine of implied conspiracy or "conscious parallelism of action," and to do so it is first necessary to define the term.

The term "conscious parallelism of action" is a label for a legal theory which represents a radical extension of a principle of law which is accepted without question; that is, that cases may be proved by circumstantial evidence. The phrase appears to have been coined by the Federal Trade Commission in the following context: ${ }^{7}$

In the Rigid Steel Conduit case, the Commission found, and the circuit court agreed, that adherence to an industry-wide basing point formula, with the knowledge that other concerns are adhering to it also, constitutes in itself a violation of the Federal Trade Commission Act by the individual adhering companies when price competition is thereby eliminated. It would have been possible to describe this state of facts as a price conspiracy on the principle that, when a number of enterprises follow a parallel course of action in the knowledge and contemplation of the fact that all are acting alike, they have, in effect, formed an agreement. Instead of phrasing its charge in this way, the Commission chose to rely on the obvious fact that the economic effect of identical prices achieved through conscious parallel action is the same as that of similar prices achieved through overt collusion, and, for this reason, the Commission treated the conscious parallelism of action as violation of the Federal Trade Commission Act. Should the Supreme Court sustain the Commission's view, the effect will be to simplify proof in basing point cases, but to expose to proceedings under the Federal Trade Commission

- "In my opinion, anyone who uses freight absorption, zone prices, or an individual universal de. livered price system, operates under the shadow of illegality and certainly is taking a calculated risk. . . . It is reasonable to say that II 8,952 business enterprises will be concerned with these decisions." Commissioner Lowell B. Mason, in Hearings before the Subcommittee of Senate Committee on Interstate and Foreign Commerce on S. Res. 24I, 8oth Cong., 2d Sess. 66-67 (1948).

T Notice to the Staff: IN re Commission Policy Toward Geographic Pricing Policies, sulpra note $x$, at 3 . Since the publication of this statement, a staff attorney for the Commission has written to the effect that, in his personal opinion, mere "conscious parallelism of action" without other evidence will not support a finding of conspiracy. Wright, Collusion and Parallel Action in Delivered Price Systems, 37 Gro. L. J. 20r, 215 (1949). In addition, the report of the subcommittec of the Senate Committee on Interstate and Foreign Commerce which investigated delivered pricing questions concluded that the Commission "appears to have written off the theory that 'conscious parallel action,' absent conspiracy, constitutes an unfair method of competition. ..." SE. Doc. No. 27, 81st Cong., ist Sess. 62 (1949). Yet, Walter Wooden, Associate General Counsel of the Commission, in a letter to the Honorable Wright Patman, member of Congress, dated June 8, 1949, and published by Congressman Patman in a release from his office dated June 14,1949 , made the following statement regarding $S$. I008 (then pending before the House): "The first section of the bill is frankly conceded by its author to be intended to cancel the law of Count II of the Rigid Steel Conduit case [see discussion of this case, infra] and there is little doubt that it does so. The result is that there would be no way of challenging a basing point system except by establishing collusion in its operation. That would relegate us to the 50-ycar-old test of the Sherman Act and destroy the philosophy of 35 years' standing that the Commission was created to arrest restraints of trade in their incipiency. ... Unless the concept of incipient restraint of trade can be applied to the basing point method of pricing the concept is an empty one and the Commission loses the thing which differentiates it from the Department of Justice as a 'remedial agency.' " There secms to have been little doube in Mr. Wooden's mind that absent legislation to the contrary the doctrine of "conscious parallelism of action" is or should be the law. 
Act only courses of action which might be regarded as collusive or destructive of price competition.

Although the term "conscious parallelism of action" is used frequently throughout this article, too much attention should not be centered on the phrase itself. As will be shown, the Commission formulated the theory long before it applied the label, and for reasons of expediency the label may, in the future, be discarded by the Commission without abandonment of the theory. Because the term "implied conspiracy doctrine" is such a broad one, however, it is convenient to use the Commission's coined phrase throughout this article to mark off for examination the extreme segment of that doctrine as the Commission's attorneys would apply it.

It seems clear that direct proof of agreement among competitors to adopt, use, or alter $^{8}$ a delivered pricing method will support an order to cease and desist from such agreement and from any similar agreement. ${ }^{9}$ It is also elementary law that agreement or conspiracy may be proved by circumstantial as well as by direct evidence. $^{10}$ Throughout its history the Federal Trade Commission has been permitted to rely upon inference in conspiracy cases. ${ }^{11}$ In principle, the doctrine of implied conspiracy may be no more than the doctrine that conspiracy may be found from circumstantial evidence. However, the Commission is now seeking to apply the doctrine far beyond previous uses, producing a trend which, if unchecked, will require no evidence of "conspiracy" in delivered pricing cases beyond the common use in an industry of a delivered pricing method, plus common knowledge of such use, plus substantial uniformity of published (list) prices. ${ }^{12}$

\section{History of Doctrine}

The evolution of the doctrine of "conscious parallelism of action" has been a gradual one. Initially, the Commission's and its attorneys' approach to delivered pricing appears to have been on the theory that it was a discriminatory and "monopolistic" practice, but not necessarily a collusive practice. The "monopolistic" theory is based on the argument that, under delivered pricing, certain phenomena

\footnotetext{
${ }^{8}$ In the Cement case, pledges were secured by the Institute from its members not to sell f.o.b. mill to purchasers' trucks, and there were other findings of actual collusion (as distinguished from noncollusive identity of action) with respect to the maintenance and operation of the basing point system. In the Rigid Sieel Conduit case, the question whether Chicago should be continued as a basing point was collectively discussed; in fact, Chicago was originally made a basing point at a 1930 meeting of the Association. There was also collective action to eliminate the Evanston basing point.

- The order may also prohibit the respondents from entering into, continuing or carrying out any "planned common course of action." The significance of this phrase is discussed infra.

${ }^{10}$ Eastern States Retail Lumber Dealers Ass'n v. United States, 234 U. S. 600, 612 (1914).

${ }^{11}$ Federal Trade Comm'n v. Pacific States Paper Trade Ass'n, 273 U. S. 52 (I927).

12 The requisite effect (i.e., restraint of trade) is presumed by the Commission, based upon its economic argument (discussed infra) that systematic industry-wide use of a common delivered pricing method stifles price competition among those using it. Knowledge of such effect on the part of the users of the method may also be presumed (according to the Commission's theory), since a man is held to contemplate the "logical" consequences of his acts. That the consequences may not appear logical to him is, of course, immaterial if the Commission thinks they are so and can persuade the courts to agree.
} 
(e.g.,-identity of prices and rigidity of prices) may appear, and that these phenomena are also observable in instances of monopoly. The argument seems to run that anything which has the effects of monopoly is tantamount to monopoly and should be unlawful. ${ }^{13}$ This, and the argument that delivered pricing is discriminatory, were the chief bases on which representatives of the Commission, during the 1930's and early I940's, sought legislation outlawing delivered pricing. ${ }^{14}$

Whether the Commission attacks industry-wide delivered pricing as "monopolistic" on the theory that it produces the effects of monopoly, or as "collusive" on the theory that it produces the effects of a conspiracy would seem unimportant. An effective conspiracy is tantamount to monopoly in the economic sense that it produces the effects of monopoly. The distinction between the "monopolistic" and the "collusive" approach to delivered pricing is important only in evaluating the historical development of the "conscious parallelism of action" doctrine and showing that its adherents are fundamentally interested in an end and not in the means used to achieve it.

The Cement case ${ }^{15}$ was the first attempt by the Commission to strike at delivered pricing on a theory of conspiracy, ${ }^{16}$ and a number of subsequently instituted cases were brought on the same theory. ${ }^{17}$ In all of these cases, however, an attempt was made by the Commission's attorneys to introduce evidence of conspiracy, i.e., evidence beyond the mere common use of a delivered pricing method with common knowledge of such use and uniformity of prices. ${ }^{13}$ Such evidence as was introduced gave rise to specific findings of conspiracy, beyond mere "conscious parallelism of action," by the Commission, ${ }^{19}$ and where these findings were reviewed, the courts affirmed them as supported by substantial evidence as required

\footnotetext{
${ }^{13}$ See findings of Commission, United States Steel Corporation, 8 F.T.C. I (1924); statements of Commissioner R. E. Freer, in Hearings before Senate Committee on Interstate Commerce on $S$. 4055, 74th Cong., 2d Sess. 309 et seq. (1936); The Basing Point Probzem 4 (TNEC Monograph 42, 194r).

${ }^{14}$ Statement of R. E. Freer, Hearings, supra note 13; The Basing Point Problem, supra note 13.

${ }^{15}$ Federal Trade Comm'n v. Cement Institute, 333 U. S. 683 (I948).

${ }^{16}$ It also contained a count charging price discrimination under the Robinson-Patman Act.

${ }^{17}$ Bond Crown \& Cork Co. v. Federal Trade Comm'n, 176 F. 2d 974 (C. C. A. 4th 1949); Allied Paper Mills v. Federal Trade Comm'n, 168 F. 2d 600 (C. C. A. 7th 1948), cert. dentied, 336 U. S. 9 I 8 (1949); Triangle Conduit \& Cable Co. v. Federal Trade Comm'n, 168 F. 2d 175 (C. C. A. 7 th 1948), aff'd per curiam sub nom. Clayton Mark \& Co. v. Federal Trade Comm'n, 336 U. S. 956 (1949); Keasbey \& Mattison Co. v. Federal Trade Comm'n, 159 F. 2d 940 (C. C. A. 6th 1947); Fort Howard Paper Co. v. Federal Trade Comm'n, 156 F. 2d 899 (C. C. A. 7th 1946), cert. denied, 329 U. S. 795 (1946); Milk \& Ice Cream Can Institute v. Federal Trade Comm'n, 152 F. 2d 478 (C. C. A. 7th 1946); United States Maltsters Ass'n v. Federal 'Trade Comm'n, I52 F. 2d I61 (C. C. A. 7th 1945); Eugene Dietzgen Co. v. Federal Trade Comm'n, 142 F. 2d 321 (C. C. A. 7th 1944); American Chain \& Cable Co. v. Federal Trade Comm'n, 139 F. 2 d 622 (C. C. A. 4th 1944); Phelps Dodge Refining Corp. v. Federal Trade Comm'n, 139 F. 2d 393 (C. C. A. 2d 1943); Salt Producers Ass'n v. Federal Trade Comm'n, 134 F. 2d 354 (C. C. A. 7th 1943).

${ }^{18}$ An exception is the second count of the Rigid Steel Condnit case, discussed infra; but treating the case as a whole without separation as to counts, evidence of conspiracy was introduced, and a conspiracy was found as to all respondents except two. The first count was dismissed as to these two, but they were found to have engaged in an unfair method of competition under the second purely by reason of "conscious parallelism of action."

${ }^{10}$ For example, see note 8 supra.
} 
by the statute. ${ }^{20}$ Thus, to date, representatives of the Commission are almost correct when they state that no case has yet been decided by the Commission or courts in which delivered pricing has been outlawed as a collusive practice in the absence of evidence of conspiracy beyond that required by the "conscious parallelism of action" doctrine. ${ }^{21}$

The first effort of the Commission to introduce the doctrine of "conscious parallelism of action" into its cases was an indirect one. The cease and desist order issued by the Commission in the Salt Producers case ${ }^{22}$ ordered the respondents to cease and desist from "entering into, continuing or carrying out, or directing, instigating, or cooperating in, any common course of action, mutual agreement, combination, or conspiracy" wtih respect to the matters specified in the order, among which was the establishment or maintenance of zone delivered pricing. This was not a case wherein the Commission sought to prove conspiracy by evidence merely of common use and knowledge of the delivered pricing method. The complaint specifically charged collusion in the establishment of the zone system, and the respondents filed answers admitting all of the material allegations in the complaint.

Respondents in the Salt Producers case obtained review of the Commission's order by the Seventh Circuit Court of Appeals, ${ }^{23}$ and, among other things, objected to the phrase "common course of action." The Commission contended that it meant nothing by the phrase except that a "common course of action" related to respondents" "admitted combination," 24 and the respondents conceded that the Commission could validly prohibit a "common course of action" which was the continuation of a conspiracy or was pursuant to an agreement. ${ }^{25}$ Respondents argued, however, that the cease and desist order would be effective to prohibit such activity without the words "common course of action."

The court decided that the disputed phrase should remain in the order but that the word "planned" should be inserted before it, making it read "planned common course of action." The court said that, with this modification, "only illegal contractual arrangements will be subject to contempt proceedings. The word 'planned' as here used is intended to cover any 'cooperative' or 'concerted' action by [respondents]. . .."26

Had the words "common course of action" remained unmodified and unexplained in the Salt Producers order, it would have been arguable in any action for

20 The statute requires in terms that the Commission's findings be supported only by "testimony," but this has been construed to mean "substantial evidence." See AtTorney Generaz's Mandat on the Administrattve Procedure Act rog (I947).

${ }^{21}$ Corwin D. Enwards, Dolng Business Under the Law as It Now Stands in Delivered Pricing aNd THE Future of AMerican Business 93 (Chamber of Commerce of the United States, 1948); see also SEN. Doc. No. 27, 81st Cong., Ist Sess. 46-63 (1949).

${ }^{22}$ Salt Producers Ass'n, 34 F.T.C. 38 (1941).

${ }^{23}$ Salt Producers Ass'n v. Federal Trade Comm'n, 134 F. 2d 354 (C. C. A. 7 th 1943).

at Id. at 357, n. 4 .

${ }^{25} I d$. at 357, n. 3 .

${ }^{20} \mathrm{Id}$. at 357 . 
violation of that order that evidence merely of parallel action in the use of a zone pricing system, without more, would establish such violation. The addition of the word "planned" and the definition of that term by the Seventh Circuit Court of Appeals made it apparent that additional evidence would be required, but how much and of what? These questions troubled the respondents in the Wire Rope case $^{27}$ against whom a cease and desist order was entered, containing the phrase "planned common course of action," shortly after the decision of the court in the Salt Producers case.

Respondents in the Wire Rope case petitioned the Fourth Circuit Court of Appeals to review the order against them, particularly the phrase above mentioned, and asked that that phrase be further modified so that, in an enforcement action, evidence of a contemporaneous agreement to follow the common course of action would be necessary. Those respondents pointed out that if two or more of them should independently decide to continue using the zone delivered pricing method which was found to have been the subject of agreement before the order was issued, they could be charged with following a "common course of action" which was "planned" in the sense that it had once been the subject of agreement, even though it would no longer be "planned" because the decision to continue it would be an independent and non-collusive one. The court refused to modify the order, but in affirming it seemed to indicate that something more than bare identity of action would be necessary as a basis for a compliance action. ${ }^{28}$

A third attempt by industry to escape the uncertain implications of "planned common course of action" failed in the Cement case, where the Supreme Court expressly sanctioned use of the phrase. ${ }^{29}$

Whether or not "planned common course of action" and its equivalent "planned concerted action" mean the same thing as "conscious parallelism of action" too

${ }^{27}$ American Chain \& Cable Co. v. Federal Trade Comm'n, 139 F. 2d 622 (C. C. A. 4th 1944).

28 "It does not seem to us that the order needs further clarification. It is of course true that a cease and desist order must be certain and unambiguous in its prohibitive terms because business men must operate under it at their peril ... [citing cases]. But, there can be no doubt that to sustain a charge of violation of the order in this case it must be shown that the prohibited acts have been performed as the result of an agreement or conspiracy, or as the result of a common course of action, that has been agreed upon or planned between two or more persons. If, as the result of such agreement or plan, the petitioners continue to cooperate in a common course of action which has been found to violate the statute, they make themselves liable to the preseribed penalties; and they have no just cause for com. plaint if in appraising the evidence in any case the triers of fact seek to determine whether there is any relation or connection between their past illegal acts and the conduct under examination. If such a relation or connection is found it may properly be condemned as a continuance of an unlawful conspiracy. Of course the influence of changed business condicions must be taken into account in reaching a decision; but there is no reason to believe that the Federal Trade Commission will fail in its duty in this respect or that the courts will hesitate to modify or reverse an order that is based on inferences not supported by the evidence." Id. at $623-624$.

${ }^{20}$ The Court said: "Respondents have objected to the phrase 'planned common course of action' in the preamble. The objection is twofold; first, that it adds nothing to the words that immediately follow it; and second, that if it does add anything, "the Commission should be required to state what this novel phrase means in this order and what it adds to the four words.' It seems quite clear to us what the phrase means. It is merely an emphatic statement that the Commission is prohibiting concerted action-planned concerted action. The Commission chose a phrase perhaps more readily understood by businessmen than the accompanying legal words of like import." 333 U. S. 683, 728 (1948). 
closely resembles the famous debates on how many angels can stand on the point of a pin. ${ }^{30}$ Suffice it to say that as a result of the Salt Producers, Wire Rope, and Cement decisions, and the inclusion in most Federal Trade Commission orders in conspiracy cases of the phrase "planned common course of action," no respondent who is subject to a cease and desist order in a case in which conspiracy to use a delivered pricing method has been found can afford the risk of continuing the particular delivered pricing method, no matter how independently he arrives at his decision to do so and no matter how lawful the independent use of that type of delivered pricing method might otherwise be. To that extent, at least, the doctrine of "conscious parallelism of action" is already the law.

Where, however, the Commission is not proceeding for the enforcement of an order against respondents already found to have conspired, but is seeking to establish initially that a delivered pricing method was collusively created or used, different considerations presently prevail; and determination of the status in the law of the doctrine of "conscious parallelism of action" requires careful appraisal. It will be apparent from such appraisal that the only thing that is clear is that the Commission has sought to make this doctrine the law. ${ }^{31}$

The best known example of an attempt to make the doctrine of "conscious parallelism of action" the law is the recent Rigid Steel Conduit case. ${ }^{32}$ There, the respondents were charged in two counts, one for conspiracy and the other for the common use, with common knowledge of such use, of a basing point system. Evidence was introduced under the first count upon the basis of which the Commission found a conspiracy, and on review by the Seventh Circuit Court of Appeals the court said, "We think there was direct proof of the conspiracy. . .."33 The second count, however, did not purport to charge conspiracy as such, but only "conscious parallelism of action," and the Commission concluded, in effect, that by their individual use of the basing point system, with individual knowledge of its common use throughout the industry, each respondent had engaged in an unfair method of competition in violation of the Federal Trade Commission Act. ${ }^{34}$

The Commission's cease and desist order in the Rigid Steel Conduit case, in addition to provisions prohibiting any further combination, conspiracy, or "planned common course of action," also contained a paragraph prohibiting each individual respondent from using the basing point system previously used or any other method of delivered pricing which would produce the effects of price uniformity or varying "mill net returns" on sales to differently located customers. ${ }^{35}$

\footnotetext{
${ }^{30}$ In the cease and desist order in the Rigid Steel Conduit case, the phrase "planned common course of action" appears in the preamble to the Count I portion of the order, whereas the phrase "conscious parallelism of action" was coined to describe the theory of Count II.

A few recent complaints have included the charge of engaging in a "common course of action." National Lead Corp., Docket No. 5253; American Iron \& Steel Institute, Docket No. 5508.

${ }^{31}$ Notice to Staff: In re Comaission Policy Toward Geographic Pricing Practices, sipra note $r$.

${ }^{32}$ Triangle Conduit \& Cable Co. v. Federal Trade Comm'n, I68 F. 2d I57 (C. C. A. 7th 1948), aff'd per ctiriam sub nom. Clayton Mark \& Co. v. Federal Trade Comm'n, 336 U. S. 956 (1949).

Id. at 180 . (Italics supplied.)

st Rigid Steel Conduit Ass'n, 38 F.T.C. 534 (I944).

35 "It is further ordered that each of the ... respondents... do forthwith cease and desist from
} 
Under pressure of a legislative inquiry into the confused state of the law on delivered pricing, representatives of the Commission sought to rationalize this paragraph in the Rigid Steel Conduit order merely as an appropriate remedy to dissipate the effects of an actual conspiracy proved by direct evidence. ${ }^{36}$ Considerable emphasis was placed by these spokesmen on the fact that the Rigid Steel Conduit case was not one in which the Commission had relied solely on "conscious parallelism of action" but one in which (under the first count of the complaint) both direct and circumstantial evidence beyond mere "conscious parallelism of action" had been adduced. ${ }^{37}$

This attempt in the legislative forum to renounce the "conscious parallelism of action" doctrine $a b$ initio was weakened by several factors: (I) the fact that two respondents (Spang-Chalfant, Inc. and Clifton Conduit Company) were exonerated by the Commission from any charge of conspiracy under the first count of the Rigid Steel Conduit complaint but were nevertheless held to have engaged in an unfair method of competition under the second count by reason of their individual use of the basing point system with knowledge that other respondents were also using it; (2) the Commission's language on page 3 of its October 12, 1948, statement of "Commission Policy Toward Geographic Pricing Practices"; and (3) statements to the Supreme Court in the Rigid Steel Conduit case to the effect that no issue of conspiracy was presented by the second count of the complaint or by the portion of the cease and desist order which required the respondents individually to refrain from delivered pricing. . $^{38}$

The Seventh Circuit Court of Appeals had affirmed the Commission's findings and order, in their entirety, in the Rigid Steel Conduit case, and, unfortunately for

doing any of the following things for the purpose or with the effect of systematically matching deliveredprice quotations with other of said respondents or producing the equivalent of such matched delivered prices through systematic discriminations in the mill nets received on sales to different purchasers:

"(a) Quoting or selling rigid steel conduit at prices calculated or determined pursuant to, or in accordance with, the basing-point delivered-price system.

"(b) Quoting or selling rigid steel conduit at delivered prices calculated as, or systematically equivalent to, the sum of the price in effect at, plus a transportation charge factor from, any point other than the actual shipping point.

"(c) Quoting or selling rigid steel conduit at delivered prices which systematically reflect the inclusion of a transportation factor greater or less than the actual cost of transportation from point of shipment to destination.

"(d) Discriminating among purchasers by quoting or selling rigid steel conduit at prices which systematically differ in terms of mill nets according to the location of purchasers, and which mill nets, plus common carrier transportation charges to the respective locations of such purchasers, produce delivered costs identical with those to such purchasers from differently located respondents." 38 F.T.C. $534,595-596$ (1944).

${ }^{38}$ Hearings before the Subcommittee of the Senate Judiciary Committee on S. 1008, 81st Cong., Ist Sess. 70 (x949).

${ }^{37}$ See Shechy, The Legal and Factual Content of Recent Geographic Pricing Cases, 37 Geo. L. J. I83, ז93-196 (1949).

${ }^{38}$ I7 U. S. L. WeEK 3293, 3295 (I949). See also Brief for Federal Trade Comm'n, pp. 2, 21, 33, Clayton Mark \& Co. v. Federal Trade Comm'n, 336 U. S. 956 (r949). However, the Government in its brief did hold in reserve the contention that if the Court found the Commission lacked authority so to deal with individual conduct, the controverted portion of the order was justified as a means of effectively dissipating the consequences of the conspiracy. Id. at 3 . 
those who hoped for a definitive clarification of the law on delivered pricing, the Supreme Court, by reason of the disqualification of one of its members and the equal division of the others, affirmed the Circuit Court's decision per curiam, without opinion. ${ }^{39}$

Thereafter, the respondents moved the Commission to reopen the proceeding and modify the paragraph prohibiting individual delivered pricing, which motion the Commission denied. ${ }^{40}$ Thus the Commission's order stands, but weakened by the Commission's own comments. ${ }^{41}$

\section{II}

\section{Theories Advanced in Support of Doctrine}

Upon what legal or other authorities did the attorneys for the Federal Trade Commission seek to construct the doctrine of "conscious parallelism of action"? A study of their briefs, public statements, and statements before Congressional committees, as well as certain court decisions, discloses that they relied upon a combination of the following:

(I) their economic arguments before Congress during the I930's and early I940's that basing point systems are "monopolistic" because they are accompanied by a rigidity and uniformity of prices which might also be found under conditions of monopoly; $;^{42}$

(2) their argument that the case of Federal Trade Commission v. Beech-Nut Packing Co. $^{43}$ establishes the principle that the Commission can find an unfair method of competition in an individual action which restrains trade even though it falls short of conspiracy; $;^{44}$ and

(3) an attempt to draw an analogy between "conscious parallelism of action" in the industry-wide use of delivered pricing and the factual situations which impelled the courts to find the existence of conspiracies in restraint of trade in Interstate Circuit v. United States, ${ }^{45}$ Bigelow v. RKO Radio Pictures, ${ }^{46}$ and William Goldman Theatres, Inc. v. Loew's, Inc. ${ }^{47}$

${ }^{30} 336$ U. S. 956 (1949).

${ }^{10}$ Rigid Steel Conduit Mfgrs., CCH Trade Reg. Serv. II 4 (Docket No. 4452, 1949). The order stated in part: "The purpose of the requested modification is said to be to make clear that the order does not prohibit any of the respondents, acting independently, from quoting or selling at delivered prices or from absorbing freight. The Commission does not consider that the order in its present form prohibits the independent practice of freight absorption or selling at delivered prices by individual sellers. What the questioned portion of the order does prohibit is the continuance of the basing-point, delivered price system, found to have been the subject of conspiracy, or any variation thereof which might be accomplished through the practices specified in subparagraphs (a), (b), (c), or (d) when done, as stated in the order, 'for the purpose or with the effect of systematically matching delivered price quotations." "

${ }^{41}$ SEN. Doc. No. 27, 8 Ist Cong., Ist Sess. 62 (1949). See also portion of order quoted note 40, supra.

${ }^{12}$ See statement of Commissioner R. E. Freer, and TNEC Monograph 42, note 13, supra.

${ }^{43} 257$ U. S. 441 (1922).

14 Shechy, stipra note 37 , at 194 .

${ }^{45} 306$ U. S. 208 (1939).

${ }^{4} 150$ F. $2 d 877$ (C. C. A. 7th 1945), rev'd on grounds not pertinent to this article, 327 U. S. 25 I (1946).

${ }^{75}$ F. Supp. rorr (E. D. Pa. 1944), rev'd, 150 F. $2 d 738$ (C. C. A. 3d 1945), cert. denied, 334 
Analysis of these economic arguments and decisions shows that they will not logically support the claim that "conscious parallelism of action" in the use of delivered pricing methods is, without more, either an unfair method of competition apart from conspiracy or sufficient evidence in and of itself of a conspiracy.

The argument that basing point systems are "monopolistic" because accompanied by price uniformity and rigidity often found in conditions of actual monopoly is necessarily based upon two theories: first, that uniformity and rigidity of prices in basing point industries are caused by the basing point system and not by something else; and second, that uniformity and rigidity of prices must be regarded as evidence of conspiracy or of a monopolistic condition, rather than as evidence of competition, or at least evidence which may point impartially either way and which should be regarded as inconclusive in the absence of other evidence.

The very fact that representatives of the Commission claim (with considerable accuracy) that every delivered pricing case decided to date by the Commission or courts (except those based entirely on the Robinson-Patman Act) has included substantial evidence, or admissions by the respondents, of actual collusion to fix prices, should suggest to the Commission that the cause of such price uniformity and rigidity as was found in those cases was not the delivered pricing method but the price-fixing conspiracy. As a matter of logic, it seems difficult to envision how a simple delivered pricing method such as freight equalization ${ }^{48}$ or "universal delivered pricing" 49 could, in and of itself, without outside assistance in the form of

\footnotetext{
U. S. 811 (1948) (same case, $\mathrm{I}_{4}$ F. $2 \mathrm{~d}$ I02I (C. C. A. $3 \mathrm{~d}$ 1948)). (Here, as will be secn infra, the decision technically did not rest on conspiracy but upon monopoly.)

${ }^{4} \mathrm{By}$ this term the writers refer to the practice of each (and every) manufacturer in an industry quoting a price f.o.b. his mill and being willing to sell at that price to any buyer who wishes to buy at the mill, whether in a truck or otherwise. Up to this point the practice would not offend the most ardent proponent of strict f.o.b. mill pricing. However, in order to be free automatically to sell in territories closer to competitors' plants and to have a quoted list price readily available for such sales, each manufacturer announces on its price list that it will "equalize freight" with any competing plant. This means that the buyer pays the manufacturer's f.o.b. mill price and pays the carrier its full, actual charge for transportation to destination. However, if such charge is greater than it would have been from some competitor's mill which is closer freightwise to the buyer, then the buyer receives an allowance in the amount of the difference. The foregoing description assumes that the f.o.b. mill prices of all manufacturers are uniform. If they are not, the manufacturer will have to do more than mercly "equalize freight." In such case, if his f.o.b. mill price plus actual freight to the buyer is higher than the f.o.b. mill price of any competitor, plus freight from that competitor's mill to the buycr, the manufacturer will give the buyer an allowance in the amount of the difference. It is noteworthy that Corwin D. Edwards, Chief Economist of the Federal Trade Commission, sees little danger of concentration of economic power under "freight equalization," or under "universal delivered pricing" described infra, note 49. See Edwards, Geographic Price Formulas and the Concentration of Economic Power, 37 Gro. L. J. 135, 147 (1949).

${ }^{2}$ By this term the writers refer to the practice of a manufacturer charging the same price delivered at any destination in the United States. This is sometimes called the "postage stamp" method of selling and is common in the case of many articles of consumer goods where freight is not an important clement of the price. The Commission is itself on record that this method of selling creates no inference of collusion, even in the parallel action of a number of competitors, where the use of the method and the uniformity of delivered prices have "simple and logical explanations in the nature of the market, the product, and the transportation cost." See FTC, Notice to THE STAFF, IN RE Commission Polici Toward Geographic Pricing Practices 4 (October, 1948). See also FTC, Price Bases Inquiry: Tiil. Basing Point Formila and Cement Prices 13 (1932).
} 
either (I) a price-fixing agreement, (2) price leadership (lawful ${ }^{50}$ or collusive), or (3) the effect of competition on a homogeneous product, ${ }^{51}$ produce price uniformity or rigidity. Although such methods of selling enable a seller to meet competitors' prices in distant markets, there is nothing in their operation that anaesthetizes his will and prevents him from beating such competitors' prices where he wishes.

The Commission's argument that industry-wide use of a delivered pricing method in and of itself produces price uniformity and rigidity is analogous to its argument in Tag Manufacturers Institute v. Federal Trade Commission. ${ }^{52}$ Respondents in that case had a price reporting plan which the Commission condemned. The evidence showed that respondents followed their list prices in 75 per cent of the dollar value of the industry's sales and sold at "off-list" prices in 25 per cent of the dollar value of the industry's sales. Since there was considerable uniformity among respondents' list prices, considerable uniformity prevailed in the 75 per cent of respondents' sales which were at list prices. The Commission found from this evidence that the price reporting plan itself was the cause of such uniformity. As to this, in setting aside the Commission's cease and desist order, the court said:53

... The evidence does not . . . warrant the Commission's finding that the effect of the operation of the Tag Industry Agreements "has resulted in a substantial uniformity of prices for tags and tag products among the respondent members." In the first place, this implies that the instances of departure from uniformity are insignificant and unsubstantial-which certainly cannot be said. In the second place, there is no evidence that such uniformity as has existed is a result of the operation of the Tag Industry Agreements, for it does not appear whether there has been an increase or decrease of uniformity either in list prices or in actual selling prices since the agreements have been in operation.

It seems significant that, even when arguing before the Temporary National Economic Committee that the basing point system in the steel industry was a "monopolistic practice" which in and of itself produced price uniformity, Walter B. Wooden, then Assistant Chief Counsel, and Hugh E. White, Examiner, of the Federal Trade Commission, were at pains to cite many printed pages of documentary evidence which they claimed showed actual collusion on prices, extras, and delivery charges. ${ }^{54}$ Thus, it appears that representatives of the Commission are themselves reluctant to rest on the proposition that delivered price methods of selling have any automatic ability to produce price uniformity.

It is beyond the scope of this article to enter the field of economic argument on the subject of price uniformity and rigidity as evidence of conspiracy. The courts have held that price uniformity may result from lawful price leadership, ${ }^{55}$ and in

${ }^{20}$ United States v. International Harvester Co., 274 U. S. 693, 708 (I927).

"1 See Rodgers and Luedicke, Dynamic Competition, 27 Harv. Bus. Rev. 237, 248 (1949).

${ }^{2}$ I74 F. 2d 452 (C. C. A. Ist I949).

${ }^{E 3} I d$. at 460 . (Italics supplied.)

- The Basing Point Problen (TNEC Monograph 42), stipra note 13, at 93-107.

c8 United States v. International Harvester Co., supra note 50; United States v. Standard Oil Co. of New Jersey, 47 F. 2d 288, 3r6-3I7 (E. D. Mo. I93I). 
a series of questions and answers submitted to the Subcommittee on Trade Policies of the Senate Committee on Interstate and Foreign Commerce, the Federal Trade Commission, through Commissioner Davis, took the following position: ${ }^{50}$

"Q. Do you think that identical prices can result from competition as well as from conspiracy?

"A. Yes."

While it is difficult to see how simple forms of delivered pricing such as "freight equalization"57 or the "universal delivered pricing" method" can logically be accused of causing, in and of themselves, any greater uniformity or rigidity of prices than would exist under any selling method which permitted several sellers to compete in the same market, ${ }^{59}$ some forms of basing point pricing may become so complex and rigid in their mechanical workings as logically to produce a greater degree of rigidity and uniformity of prices than would obtain in their absence. This is really the burden of the Commission's objection to "Pittsburgh Plus" in the steel industry $;^{60}$ to the multiple basing point system as it existed in the steel industry during the days of T.N.E.C.; ${ }^{61}$ and to the multiple basing point systems found in the Cement and Rigid Steel Conduit cases. ${ }^{62}$ However, in instances like these it is likely that evidence of actual conspiracy to hold the system together will be found. As has aptly been said by an attorney on the Commission's staff: ${ }^{03}$

The necessity for identical transportation factors, for refusing to permit delivery to trucks or water carriers, for preventing "diversion in transit," and for unified action in every other respect in which a price advantage can be created for any seller, makes it unlikely that such a system can be made to produce continued identity of prices without leaving a trail of evidence sufficient to condemn the venture.

The second major argument used by attorneys for the Commission in constructing the doctrine of "conscious parallelism of action" is that the Beech-Nut case establishes the principle that the Commission can find an unfair method of competition in individual action that falls short of conspiracy. In a footnote to its

${ }^{50}$ Sen. Dor. No. 27, 81st Cong., Ist Sess. 62 (I949).

${ }^{57}$ See note 48 supra.

${ }^{58}$ See note 49 supra.

${ }^{50}$ Strict f.o.b. mill pricing would logically provide direct price competition only at the boundarics of the various sellers' territories, assuming only one mill at each production point. If two or more competing mills were located at the same point, they would, of course, compete directly throughout their territory, but in such case it seems logical that uniformity of prices would tend to exist among them to the extent that their products were homogeneous. If price uniformity is to be blamed on the pricing method, it could here be blamed upon the f.o.b. mill pricing method. Such method could also be charged with responsibility for the uniformity of price which would be likely to occur at boundaries between competing mill territories. The writers feel, however, that in neither of these instances, nor in the case of the simpler forms of delivered pricing, can the method of selling logically be blamed for a condition which will occur under any method of selling which permits sellers to compete in the same market.

${ }^{80}$ United States Steel Corp., Docket No. 760, aff'd by consent Oct. 5, 1948 (C. C. A. 3d 1948).

${ }^{01}$ The Basing Point Problem (TNEC Monograph 42, 1941), supro note 13.

${ }^{62}$ See Edwards, supra note 48 , at $135-146$, wherein it is apparent that the systems he is describing and criticizing involved non-basing point mills, organized "disciplining" of price-cutters, etc. Compare this with his discussion of "freight equalization" and the uniform delivered price, id. at 147 .

${ }^{\circ 3}$ Wright, supra note 7 , at 214 . (Italics supplied.) 
majority opinion in the Cement case, ${ }^{64}$ the Supreme Court cited the Beech-Nut case as authority for the abstract proposition that the existence of a combination is not an indispensable ingredient of an unfair method of competition under the Federal Trade Commission Act. This statement was pure dictum because of the categorical holding of the Court that the Commission's findings of combination were supported by evidence. ${ }^{65}$

The Beech-Nut case involved a complex system established by the Beech-Nut Packing Company for the purpose of policing violations of its "suggested" resale prices. The earlier decision in United States v. Colgate ${ }^{66}$ had held that it was lawful for a manufacturer to announce to its dealers suggested resale prices and further to announce a policy of refusing to sell to those dealers who did not comply with the suggestion, so long as no agreement was made and the dealer was free to comply or not, risking only the possibility of being cut off from further supplies by the manufacturer.

The Beech-Nut Company followed the principle of the Colgate case but went further. It established a system involving black lists and white lists, encouragement of dealers to report price-cutters, reinstatement of previously cut off dealers upon satisfactory "assurances" that they would comply with the suggested prices in the future, and the general organization of all dealers to cooperate in maintaining the resale price policy of Beech-Nut.

The case was decided upon an agreed statement of facts upon which the Commission felt constrained, for some reason, to make a specific finding that the merchandising conduct of Beech-Nut did not "constitute a contract or contracts whereby resale prices are fixed, maintained or enforced." "Th The reviewing court was thus forced into the position of determining the legality or illegality of the system under the Federal Trade Commission Act, apart from any agreement, notwithstanding that the Commission might well have found that the cooperative activities between Beech-Nut and its dealers did constitute an agreement, combination or conspiracy.

The Court upheld the Commission's conclusion that the Beech-Nut system was an unfair method of competition, but it is noteworthy that the Court regarded the Commission's cease and desist order as too broad and modified it to prohibit only those activities of Beech-Nut which exceeded the simple suggestion of resale prices and announcement of a refusal-to-sell policy, sanctioned by the Colgate decision. Thus, the Court, unlike the Commission, was not prepared to deprive Beech-Nut of the independent right to use a lawful selling method merely because its prior use thereof had exceeded the bounds of legality by the addition of other practices involving active cooperation with its dealers.

\footnotetext{
${ }^{04} 333$ U.S. 683,721 n. Ig (1948).

${ }^{00}$ See Justice Burton dissenting, id. at 732-733.

${ }^{08} 250$ U. S. 300 (1919).

${ }^{67} 257$ U. S. $44 \mathrm{I}, 455$ (1922).
} 
There seems little doubt that, in the Beech-Nut case, the cooperative activities of Beech-Nut and its dealers were in fact collusive, even though there were no formal written contracts with the dealers such as were condemned in Dr. Miles Medical Company v. Park \& Sons Company. ${ }^{88}$ The Commission's finding that the activities of Beech-Nut and its dealers did not constitute a "contract or contracts" may be taken to mean merely that there were no contracts of the Dr. Miles type, and the decision may then be rationalized on the principle that agreements in restraint of trade may readily be implied from evidence as direct as that in the Beech-Nut case. If not thus rationalized, the decision would seem to fit only the principle of a hard case making bad law.

A majority of the Federal Trade Commission has taken the public position that: ${ }^{68}$

Each seller may choose his own method of pricing provided that he does not conspire or agree with his competitors and provided that he does not discriminate in price in the manner prohibited by law and thereby injure competition or tend to create a monopoly. A seller may absorb freight or absorb part of his manufacturing costs or any other costs in order to in good faith meet an equally low price of a competitor.

If an individual seller may do these things, the fact that two or more competing sellers do them independently should not be treated as an unfair method of competition under the principle of the Beech-Nut case. If there was evidence of agreement, then the agreement would be unlawful and should be prohibited. Evidence of agreement might be spelled out of activities of the respondents beyond the mere common use of a delivered pricing method with consciousness of such common use, just as the activities of Beech-Nut and its dealers beyond the mere announcement by Beech-Nut of suggested prices and a refusal-to-sell policy spelled out what was in essence an agreement, despite the Commission's finding that they did not constitute a "contract or contracts." But, as in the Beech-Nut case, the cease and desist order should be modified if it prohibits any respondent from further use of delivered pricing in the absence of agreement or unlawful discrimination in such use. In this respect, it is submitted, the order in the Rigid Steel Conduit case went too far.

The third major argument used by attorneys for the Commission in constructing the doctrine of "conscious parallelism of action" is that common, conscious use of the same delivered pricing method by competing members of an industry is analogous to the factual situations which impelled the courts to find the existence of conspiracies in restraint of trade in Interstate Circuit v. United States, Bigelow v. RKO Radio Pictures, and William Goldman Theatres, Inc. v. Loew's, Inc.

The Interstate Circuit case arose out of a series of substantially identical contracts between defendant Interstate, an important motion picture exhibitor in Texas, and

18220 U. S. 373 (19II).

${ }^{89}$ Sen. Doc. No. 27, 81st Cong., Ist Sess. 62 (1949). 
eight major motion picture distributors. ${ }^{70}$ The District Court $^{71}$ found that the distributors had conspired among themselves and with Interstate with regard to these contracts, and further that the contracts themselves violated the Sherman Act. Appeal was taken directly to the Supreme Court, which affirmed. ${ }^{\mathbf{2}}$

Had the Supreme Court stopped with its holding that the trial court's finding of conspiracy among the distributors was supported by evidence, the case would

${ }^{70}$ Defendant Interstate owned virtually all of the first-run moving picture theatres in six Texas cities. The court found that it and an affliated company, also a defendant, "dominate the motion picture business in the cities where their theatres are located." In these cities, they were in competition with moving picture theatres that showed Class A pictures in second runs (pictures shown for the second time in the same city), and also pictures below Class $A$ in quality. Interstate generally charged 40 cents admission in its first-run theatres, while competing second-run theatres charged much lower prices, as low as ro or 15 cents, and also sometimes offered double features.

In July r934 Interstate's general manager wrote a letter to the local Texas branch managers of the eight major motion picture distributors, stating in substance that Interstate would have to cut its 40 -cent admission price unless these distributors agreed that, in licensing their Class $A$ films to sccond-run theatres in the cities concerned, they would require the latter not to charge less than 25 cents admission and not to run such films as part of any double feature program. The letter was a joint missive addressed to all of the branch managers of the eight distributors, each of whom received a copy of it.

Each of the distributors' branch managers disclaimed authority to make any such agreement with Interstate, and referred the matter to his principal. It appeared that conferences were then held by each distributor separately with Interstate, and eventually each distributor entered into a contract with Interstate embodying substantially the terms of Interstate's demand. There was no direct evidence that the distributors agreed or even conferred among themselves on the subject, but on the other hand no executive officer or other official of the distributors, except the branch managers, appeared as a witness.

$7 x$ 20 F. Supp. 868 (N. D. Tex. I937).

${ }^{73}$ With respect to the evidence from which the district court drew its inference of conspiracy, the Supreme Court said:

"The trial court drew the inference of agreement from the nature of the proposals made on behalf of Interstate and Consolidated [Interstate's affiliate]; from the manner in which they were made; from the substantial unanimity of action taken upon them by the distributors; and from the fact that appellants did not call as witnesses any of the superior officials who negotiated the contracts with Interstate or any official who, in the normal course of business, would have had knowledge of the existence or nonexistence of such an agreement among the distributors. ..." 306 U. S. 208, 22 I (I939).

The Court pointed out that each of the distributors had received a copy of the Interstate letter which named on its face all of the distributors to whom it was sent. With respect to the subsequent unanimity of action by the distributors, the Court said:

". . . It taxes credulity to believe that the several distributors would, in the circumstances, have accepted and put into operation with substantial unanimity such far-reaching changes in their business methods without some understanding that all were to join, and we reject as beyond the range of probability that it was the result of mere chance." Id. at 223.

With respect to appellants' arguments that inferences other than that of agreement might be drawn from their acts, the Court said:

"... we decline to speculate whether there may have been other and more legitimate reasons for such action not disclosed by the record, but which, if they existed, were known to appellants." Id. at 225. (Italics supplied.)

The Court adverted to the fact that appellants had failed to put on the witness stand any officer or person who knew or should have known of the existence or non-existence of any conspiracy among the distributors. It said that when the proof supported the inference of conspiracy the burden of going forward with evidence to explain or contradict it shifted to the appellants, but that they undertook to carry out that burden only by calling as witnesses their local branch managers each of whom testified that he had had no conferences with other distributors or their representatives. The Court then said:

". . . The failure under the circumstances to call as witnesses those officers who did have authority to act for the distributors and who were in a position to know whether they had acted in pursuance of an agreement is itself persuasive that their testimony, if given, would have been unfavorable to appellants. The production of weak evidence when strong is available can lead only to the conclusion that the strong would have been adverse. Clifton $v$. United States, 4 How. 242, 247. Silence then becomes cvidence of the most convincing character [citing other cases]." Id. at 226. 
have afforded little or no aid in the construction of the Federal Trade Commission's doctrine of "conscious parallelism of action," although it does, of course, substantiate the undisputed doctrine that conspiracies can be found from circumstantial evidence. The circumstantial evidence in the Interstate case involved, however, far more than mere parallel action and consciousness of it in a situation where parallel action is to be expected because induced by the legitimate desire to sell in distant markets and the necessity of meeting competitors' prices in order to do so. The distributors in the Interstate case made drastic changes in their business practices as the result of pressure put on them from the outside, i.e., by Interstate. It is noteworthy that, in this part of its opinion, the Court supported the District Court's finding that there had been a conspiracy among the distributors themselves, apart from their independent conferences with Interstate, and did not indicate that in the absence of such a conspiracy, parallel action by the distributors would have been unlawful. In fact, the stress laid by the Court on the absence of testimony by the officers of the distributors implies that had such officers explained away or rebutted the prima facie case of conspiracy created by the circumstantial evidence in the record, the parallel action would have been lawful.

The Court, however, did not stop with its holding that the District Court's finding of conspiracy was supported by the record, but continued with what it is submitted may be characterized as dictum; $;^{73}$ and it is this dictum which laid the foundation for the Federal Trade Commission's doctrine of "conscious parallelism of action": ${ }^{74}$

While the District Court's finding of an agreement of the distributors among themselves is supported by the evidence, we think that in the circumstances of this case such agreement for the imposition of the restrictions upon subsequent-run exhibitors was not a prerequisite to an unlawful conspiracy. It was enough that, knowing that concerted action was contemplated and invited, the distributors gave their adherence to the scheme and participated in it. Each distributor was advised that the others were asked to participate; each knew that cooperation was essential to the successful operation of the plan. They knew that the plan, if carried out, would result in a restraint of commerce, which, we will presently point out, was unreasonable within the meaning of the Sherman Act; and, knowing it, all participated in the plan. The evidence is persuasive that each distributor early became aware that the others had joined. With that knowledge they renewed the arrangement and carried it into effect for the two successive years.

It is elementary that an unlawful conspiracy may be and often is formed without simultaneous action or agreement on the part of the conspirators. Schenck v. United States, 253 Fed. 212, 213, aff'd 249 U. S. 47; Levey v. United States, 92 Fed. 2d 688, 69r. Acceptance by competitors, without previous agreement, of an invitation to participate in a plan, the necessary consequences of which, if carried out, is restraint of interstate commerce, is sufficient to establish an unlawful conspiracy under the Sherman Act. Eastern States Lumber Assn. v. United States, 234 U. S. 6oo; Lawlor v. Loesve, 235 U. S.

${ }^{73}$ This is doubly true because, in addition to the holding of conspiracy, the Supreme Court sustained the lower court's judgment and decree upon the ground that each individual contract between a distributor and Interstate was a contract in unreasonable restraint of trade, apart from any conspiracy among the distributors themselves.

74 306 U. S. 208, 226-7 (1939). 
522, 534; American Column Co. v. United States, 257 U. S. 377; United States v. American Linseed Oil Co., 262 U. S. 37 r.

Certain highlights in the foregoing quotation should be kept in mind. First, the Court said that agreement among the distributors was not a prerequisite to an unlawful conspiracy "in the circumstances of this case." Second, the knowledge imputed to the distributors was not mere knowledge that parallel action existed but knowledge that "concerted action was contemplated and invited." Third, knowledge was required that the plan, if carried out, "would result in an [unreasonable] restraint of commerce."

Each of these elements would distinguish this case from a situation in which sellers independently and individually elected, for example, to sell at a price which was the same delivered anywhere in the United States or to sell on a basis whereby each equalized or absorbed freight with the others so as to sell in the others' territories. In such a situation, although parallel action would exist, it would not be "invited" and would not necessarily be "contemplated." The condition would not suddenly come into existence as the result of a plan circulated by one of the sellers (or by an outsider) to all concerned. The situation would, moreover, be explainable in the nature of the homogeneity of the product and the necessity for meeting competitors' prices, and there is no reason why the sellers would not take the witness stand, explain their individual and independent actions and the business reasons which motivated them, and thus rebut any inference of conspiracy.

Moreover, in a simple delivered pricing situation of the type described, it could not validly be said that the sellers, although they might know of the parallel action in their industry (such knowledge being hard to avoid by an alert business man), would be chargeable with knowledge that such parallel action restrained trade unreasonably. Any argument to the contrary would have to be based on the Commission's apparent view that price uniformity restrains trade whether it is the result of conspiracy or competition, and the further view that where price uniformity exists under a delivered pricing method, it is the method of selling and not something else that is the operating cause of it. We have already attempted to demonstrate the unsoundness of both theories.

Thus, the Interstate Circuit decision does not justify the doctrine of "conscious parallelism of action" as the Commission would seek to apply it, i.e., by proof only of common use and common knowledge of the use of a delivered pricing method in an industry, plus evidence of the uniformity of prices.

Language in the Bigelow and Goldman cases goes a little further in the direction of the Commission's theory of "conscious parallelism of action" than does the language of the Interstate Circuit case, but the cases do not support the theory.

The Bigelow case was a suit for treble damages under the Sherman and Clayton Acts based upon an alleged conspiracy among motion picture distributors in Chicago to maintain a distribution system under which minimum admission prices of theatres were fixed, and each theatre was classified as to the period when it might 
exhibit feature films. ${ }^{75}$ The case was tried before a jury on two alternative and mutually exclusive theories, ${ }^{76}$ one being that there was an unlawful conspiracy among the distributor-defendants to maintain the distribution system, and the other being that there was an unlawful conspiracy among the distributor-defendants (even though their maintenance of the system might be non-collusive) to discriminate against the plaintiffs' theatre in the matter of its classification. The jury returned a general verdict for the plaintiffs and, on appeal, the Seventh Circuit Court of Appeals undertook, by deductive reasoning, to ascertain upon which of the two theories the jury had based its verdict. The court decided that the jury had based its verdict on the first theory (conspiracy to maintain the system) and that such verdict was supported by the evidence. However, it reversed the trial court's judgment with instructions to enter judgment for the defendants non obstante veredicto on the ground that the plaintiffs had not proved damages. Plaintiffs appealed to the Supreme Court, which held that the plaintiffs had proved damages and reversed the judgment of the court of appeals and affirmed that of the district court.

There is nothing in the opinions of either the circuit court of appeals or the Supreme Court which sheds any light on the nature or scope of the evidence which was held to support the jury's verdict of conspiracy to maintain the distribution system. ${ }^{77}$ The following statement of the circuit court of appeals is the one relied upon by the Federal Trade Commission as justification for its "conscious parallelism of action" doctrine: ${ }^{78}$

Knowing participation by competitors without previous agreement in a plan, the necessary consequences of which if carried out is unreasonable restraint of interstate commerce, is sufficient to establish an unlawful conspiracy.

In support of this statement the court cited the dictum hereinbefore quoted from the Interstate Circuit case. However, without knowing the nature and scope of the evidence which was before the jury, the statement must be regarded as dictum, as it was in the Interstate Circuit case. ${ }^{79}$

${ }^{75}$ Plaintiffs owned a theatre in a neighborhood section of the city which was in competition with theatres owned by the film distributor-defendants. Plaintiffs' theatre, under the system, was not permitted to exhibit feature films until ten weeks after such films had completed their showing in the downtown Loop section of the city where the theatres were owned by the distributor-defendants. The distribution system was uniform in all of its details among the distributor-defendants, i.e., the same minimum admission prices were required by all distributor-defendants of each class of theatres and their classification of theatres was uniform. Plaintiffs had sought, unsuccessfully, to have their theatre reclassified into a more favorable grouping so it could obtain feature pictures a shorter time after they had been shown in the Loop.

${ }^{70}$ The circuit court of appeals held that the plaintiffs had admitted that the two theories were mutually exclusive, and thus bound themselves by the admission, whether the theories would otherwise have been so regarded or not.

${ }^{77}$ Beyond outlining the general nature of the motion picture industry, the details of the distribution system itself, the fact that all defendants used it, and the evidence regarding plaintiffs' damages, ncither court discussed the evidence at all, except that the circuit court of appeals said that ". . . no specific agreement to enter into such conspiracy on the part of the defendants was proven. . . " I50 F. $2 \mathrm{~d}$ 877,882 (C. C. A. $7_{\text {th }}$ 1945). This might, of course, mean only that no direct proof of agreement was made but that there was sufficient circumstantial evidence beyond mere unanimity of action.

${ }^{78} 150$ F. 2 d $877,882,883$ (C. C. A. 7 th 2945 ).

${ }^{70}$ It is interesting that the circuit court of appeals distinguished two other cases: Gary Theatre Co. v. 
It is evident that the decision neither of the circuit court of appeals nor of the Supreme Court ${ }^{80}$ in the Bigelow case, as written, can be said to have extended, or made into law, the original dictum in the Interstate Circuit case.

The final case relied upon by the Commission to support its doctrine of "conscious parallelism of action" is the Goldman case. Plaintiff Goldman, lessee of a downtown motion picture theatre in Philadelphia, was uniformly refused first-run films by all distributors, although it offered higher rental fees than the single exhibitor (Warner) which controlled all the other downtown theatres. ${ }^{81}$

Plaintiff Goldman brought an action for an injunction and treble damages for violation by the defendants of Sections $I$ and 2 of the Sherman Act. The trial court found that, with respect to Section $I$, "Uniformity of action . . . without more, is not evidence of agreement or conspiracy." 82 On the question of Section 2, the lower court held, in substance, that while the effect of the distributors' contracts to lease first-run pictures only to Warner was to give Warner a monopoly of such pictures in Philadelphia, a monopoly of so small a part of commerce was not unlawful unless there was an intent to monopolize, which he found did not exist. He therefore entered judgment for defendants, and plaintiff appealed.

Columbia Pictures Corp., x20 F. 2d 89I (C. C. A. 7th I94I) and Westway Theatre v. Twentieth Century Fox Film Corp., 30 F. Supp. 830 (Md. 1940), aff'd, Ir3 F. 2 d 932 (C. C. A. 4th 1940) (in which the defendants had also followed an identical distribution system for moving pictures), on the ground that in each of those cases the district court had found no conspiracy and the circuit court of appeals was bound by such finding of fact. If, as a matter of law, "conscious parallelism of action" is tantamount to conspiracy, it would seem illogical to leave the trial courts and juries carte blanche discretion to decide either way on the subject. The inference is that in the Bigelow case there was at least circumstantial evidence of conspiracy beyond mere "conscious parallel action," while in the Gary and Westway cases there was either no such additional evidence or evidence negativing any inference of conspiracy.

${ }^{80}$ The decision of the Supreme Court in the Bigelow case does not shed much light on the question under discussion. In that Court, the defendants abandoned their attack on the jury's finding of conspiracy, and the sole question was whether the plaintiffs had proved damages. The Supreme Court did say:

"There was evidence from which the jury could have found that respondents maintained in the Chicago district, by a conspiracy among themselves, a discriminatory system of distributing motion pictures for showing in successive weeks of release. .." 327 U. S. 25I, 255 (I946).

And later it said:

"... evidence was introduced in the course of the trial tending to show that respondents conspired to maintain the release system as part of a conspiracy to maintain minimum admission prices to be charged by exhibitors generally. ..." Id. at 257 .

These statements are, again, some indication that the evidence before the jury went beyond that of mere "conscious parallelism of action."

${ }^{81}$ Distributors of motion pictures controlling the production and distribution of 80 per cent of the feature pictures available for distribution in the United States had contracts with a single exhibitor (Warner Brothers) owning seven first-run motion picture theatres in Philadelphia. These contracts required the distributors to furnish first-run feature pictures only to Warner. Plaintiff, who had been in the motion picture exhibition business in Philadelphia for many years, rented a theatre in downtown Philadelphia suitable for the showing of first-run pictures. Before doing so, plaintift was informed by one of the distributor-defendants that the latter would very likely lease him first-run pictures because it was dissatisfied with Warner Brothers. However, after renting the theatre, plaintiff applied to all of the distributors for first-run pictures and was uniformly refused by all, notwithstanding that it offered them higher rental fees than Warner Brothers.

${ }^{82} 54$ F. Supp. IoIr, Ior3 (E. D. Pa. I944). 
The Third Circuit Court of Appeals reversed the judgment and remanded the case to the district court to take evidence with respect to plaintiff's damages and to formulate an appropriate decree. ${ }^{83}$

The decision of the circuit court of appeals contains somewhat indiscriminate references to both "conspiracy" and "monopoly," but appears clearly to have been based on a rejection of the lower court's holding that a local monopoly is not unlawful without specific intent to monopolize. ${ }^{84}$ While Section 2 of the Sherman Act prohibits not only monopolization and attempts thereat but also combinations and conspiracies to monopolize, the decision of the Circuit Court of Appeals can be, and apparently is, rationalized on the theory that the effect of the contracts between the distributors and Warner gave Warner an absolute monopoly of a portion of interstate commerce, i.e., the showing of first-run pictures in Philadelphia, and that the limited nature of the monopoly did not exempt it from the Sherman Act. The court's discussion of conspiracy, therefore, may well be regarded as dictum. However, it should not be ignored because it contains language relied upon by the Federal Trade Commission to support its "conscious parallelism of action" doctrine. The precise language is $:^{85}$

Uniform participation by competitors in a particular system of doing business where each is aware of the other's activities, the effect of which is restraint of interstate commerce is sufficient to establish an unlawful conspiracy under the statutes before us.

As to the conspiracy charge, the court noted that the plaintiff had put on proof of his own ability to operate a first-run theatre, the suitability of his theatre for first-run pictures, and the uniform refusal of each distributor to lease him (or anyone except Warner) first-run pictures. In addition the plaintiff showed that he had served interrogatories on each of the defendant distributors asking why it had refused him first-run pictures, and that their answers were evasive and not factual or responsive. One answered that its arrangement with Warner gave it "economic advantages"; another that it was "more advantageous"; a third that it was "desirable"; and a fourth that it was "very satisfactory"-this in spite of the fact that plaintiff had offered them more money for first-run pictures than Warner.

In view of this evidence, ${ }^{86}$ the Goldman case, it is submitted, cannot be regarded

${ }^{83} 150$ F. 2 d 738 (C. C. A. 3rd 1945).

84 That the circuit court based its decision on Section 2, not Section I, of the Shcrman Act is apparent from its opening statement:

"The question we meet is whether plaintiff has supported its charge of illegal monopoly that defendants have violated Section 2 of the Sherman Act . . . in order to support an action for injunctive relief and triple damages under Section 4 of the Clayton Act. ... Plaintiff relied too on Section I of the Sherman Act ... ; and while this section states an additional offense 'the two sections overlap in the sense that a monopoly under Section 2 is a species of restraint of trade under Section I.' "Id. at 740.

SE Id. at 745 .

${ }^{86}$ The court, commenting upon this evidence, said it showed that "there is concert of action in what has been done and that this concert could not possibly be sheer coincidence. We think there must have been some form of informal understanding." Id. at 743 .

The Court then laid stress on the fact that defendants had put in no evidence at all to rebut or explain the inference of conspiracy, and cited and quoted from the Interstate Circtit decision on the failure of defendants in such situations to produce their responsible executive officers to testify. 
as authority for the "conscious parallelism of action" doctrine, as the Federal Trade Commission would apply it to delivered pricing cases. Industry-wide use of delivered pricing has been loosely characterized by the Commission's spokesmen as a "monopolistic" practice, but this charge has proceeded from the argument that delivered pricing is the cause of price uniformity and that price uniformity is an evil in and of itself. In the Goldman case the result of the distributors' contracts with Warner was a true monopoly, in the traditional sense of the term, even though it applied to a limited geographical area and a limited product. Knowledge of that fact on the part of the distributors was proved, but that knowledge is far different from the mere knowledge acquired by a business man from his dealings in the trade that he is using a delivered pricing method which is the same as his competitors and that, when he meets competitors' prices, there will be price uniformity.

The Goldman case may stand for the proposition that a seller may not safely make a contract to sell exclusively to one buyer if he knows that all other sellers are doing likewise with a resulting monopoly in that buyer. To the extent that the Goldman case enters the field of implied conspiracy, however, it must be limited to its facts, including the fact of actual monopoly and the fact that (as in the Interstate Circuit case) the defendants refused to testify in an effort to explain away the inference of an informal understanding.

\section{III}

\section{Present Legal Status of Doctrine}

However illogical may be thought the Commission's position in adopting and advocating its "conscious parallelism of action" theory, as long as the Commission occupies its present status as a "body of experts" that theory cannot be lightly written off. The courts may be on the verge of changing the theory into a rule. That this has not yet occurred, but that latent possibilities exist is shown by examination of (I) the Rigid Steel Conduit case, (2) the Supreme Court opinion in the Cement case, (3) a series of opinions of the Seventh Circuit Court of Appeals, and (4) the Crown Manufacturers case. ${ }^{87}$

The Rigid Steel Conduit case shows both the trend and its non-realization. On the one hand is a cease and desist order embodying the "conscious parallelism of action" theory, and affirmance of that order by both the Seventh Circuit Court of Appeals and the Supreme Court. On the other hand, the Supreme Court affirmed merely by virtue of a four-to-four vote. Neither court produced an opinion which really upholds the "conscious parallelism of action" theory, ${ }^{88}$ and the Commission has disclaimed the apparent effect of the case as a precedent. ${ }^{89}$

The Seventh Circuit Court of Appeals, in its opinion, obviously erred in basing its discussion of the Count II issues on the premise that: "In this situation, and

\footnotetext{
${ }^{87}$ Bond Crown \& Cork Co. v. Federal Trade Comm'n, x76 F. 2d 974 (C. C. A. 4th 1949).

${ }^{80}$ See note 43 supra.

${ }^{88}$ There was no opinion by the Supreme Court, of course.
} 
indeed all parties to these proceedings agree, the legal question presented is identical with the one the Supreme Court considered in the Federal Trade Commission v. Cement Institute case."90 The Rigid Steel Conduit case was argued to the Circuit Court of Appeals on January I9, r948, or several months before the Cement case was decided by the Supreme Court. The issues decided by the circuit court of appeals in the Cement case were (I) that the Commission failed to find a conspiracy, (2) that assuming adequate findings of a conspiracy the evidence did not support such findings, and (3) that in the absence of a conspiracy the use of the multiple basing point system by the cement industry did not constitute an unfair method of competition. It was this third issue decided by the circuit court of appeals to which the comparison was made when the Rigid Steel Conduit case was argued in that court. In subsequently deciding the Cement case, the Supreme Court held that there were findings of a conspiracy and that the evidence did support such findings, so that the Supreme Court, as Justice Burton's dissent points out, ${ }^{01}$ did not reach the third issue which comprised the bulk of the lower court's opinion in the Cement case.

Following this misapprehension, the circuit court of appeals in the Conduit case quoted from the Supreme Court opinion in the Cement case language which probably is dictum and which certainly relates only to a minor collateral issue ${ }^{02}$ in that case ${ }^{03}$

... individual conduct, ... . which falls short of being a Sherman Act violation may as a matter of law constitute an "unfair method of competition" prohibited by the Trade Commission Act. A major purpose of that Act . . . was to enable the Commission to restrain practices as "unfair" which, although not yet having grown into Sherman Act dimensions, would most likely do so if left unrestrained. The Commission and the courts were to determine what conduct, even though it might then be short of a Sherman Act violation, was an "unfair method of competition."

Without further discussion the Seventh Circuit Court of Appeals then concluded that it could not say the Commission was wrong in holding that the individual use of the basing point method as used in the rigid steel conduit industry constituted an unfair method of competition.

Thus the Seventh Circuit Court of Appeals did not discuss the merits or demerits of the "conscious parallelism of action" theory, but apparently adopted the view that the Commission, as a "body of experts," must be supported by the reviewing courts.

Similarly, whatever significance the Supreme Court's opinion in the Cement case may have in this connection lies in the broad insistence that the conclusions of the Federal Trade Commission must be accepted. There are two portions of the opinion which the Commission might cite in support of its "conscious parallelism

${ }^{30}$ I68 F. 2 d 175, I8I (C. C. A. 7 th 1948 ).

${ }^{02}$ See 333 U. S. 683,737 (1948), dissenting opinion of Justice Burton.

${ }^{22}$ The question whether Cement Mfrs. Protective Ass'n v. United States, 268 U. S. 588 (1925), was controlling, or relevant, as to the issues in the instant case.

${ }^{93} 168$ F. 2d 175 , r 81 (C. C. A. 7 th 1948). 
of action" theory. One is that which was seized on by the Seventh Circuit Court of Appeals in its Rigid Steel Conduit opinion, quoted supra. The other, in substance, was that the Commission was not wrong "in concluding that the deliveredprice system as here used provides an effective instrument which, if left free for use of the respondents, would result in complete destruction of competition and the establishment of monopoly, in the cement industry. . . . We uphold the Commission's conclusion that the basing point delivered price system employed by respondents is an unfair trade practice which the Trade Commission may suppress." This statement was followed by a footnote to the effect that existence of a combination is not an indispensable ingredient of an unfair method of competition.

Neither of these points seems, however, to be directly pertinent to the question of proof of implied conspiracy. Each seems rather to relate to possible authority of the Federal Trade Commission to prohibit entirely individual use of delivered price systems, which the Commission has disclaimed any intention of doing. However, these statements might be used by the Commission to support its contention that collective use of a delivered price system for the purpose or with the effect of "matching" prices is an unfair method of competition, although independent delivered price selling is not. The distinction between such a contention and the doctrine of "conscious parallelism of action" is, for practical purposes, non-existent. Whether conspiracy is inferred automatically from a state of facts or such state of facts is held illegal per se would seem unimportant except to metaphysicians.

In addition to the chance that the Commission may be granted power specifically to apply its "conscious parallelism of action" theory eo nomine, there is also some possibility that the Commission may achieve an equivalent authority indirectly by being supported in the calling of identical prices accompanied by delivered price selling a conspiracy instead of "conscious parallelism of action," as the Commission originally asserted it might do. ${ }^{95}$ In a group of recent court decisions there is a substantial quantity of dicta which, in the hands of clever brief writers and careless opinion writers, might ultimately be the vehicle for importing the theory of "conscious parallelism of action" into the law by another name. These dicta occur in five opinions of the same court, the Seventh Circuit Court of Appeals, in five delivered pricing cases where actual conspiracy was found to exist.

The first of this series is the Maltsters case. ${ }^{96}$ There the Federal Trade Commission charged and found a direct price-fixing agreement, made effective in part through use of a Chicago-plus, or single basing point, system. Although the respondents were shown to have engaged in activities which under the substantial evidence rule seemingly would have warranted affirmance of the Commission's order without regard to the use of the delivered price system, the court said::77

\footnotetext{
${ }^{\circ 4} 333$ U. S. $683,720-721$ (1948).

${ }^{25}$ See page 228 supra.

${ }^{\circ 0}$ United States Maltsters Ass'n v. Federal Trade Comm'n, I52 F. 2d 16I (C. C. A. 7th I945).

${ }^{\circ 7} I d$. at 164 .
} 
The fact that petitioners utilized a system which enabled them to deliver malt at every point of destination at exactly the same price is a persuasive circumstance in itself. Especially is this so when it is considered that petitioners' plants are located in four different states and that the barley from which the malt is manufactured is procured from eight or nine different states.

The Maltsters case was followed, chronologically, by the Milk Can case, ${ }^{08}$ the Crepe Paper case, ${ }^{99}$ the Rigid Steel Conduit case ${ }^{100}$ (that portion of the opinion dealing with Count $I$, the finding of a conspiracy), and the Book Paper case. ${ }^{101}$ In the Book Paper case the Court came close to inviting the Commission to put the "conscious parallelism of action" theory into effect under a conspiracy label:102

The petitioners did with varying uniformity use the zoning system of price quoting, and the existence of this plan which equalizes delivered prices of competitors having widely different costs at a given destination, is strong evidence in itself of an agreement to use such plan. [Citing Rigid Steel Conduit and Crepe Paper cases.] Moreover, a uniform participation by competitors in a particular system of doing business, where each is aware of the others' acts and where the effect is to restrain commerce, is sufficient to establish an unlawful conspiracy. [Citing the Goldman case.]

It may be too much to hope that in future cases the courts will keep these quotations in their proper frame of reference. In each of those five cases there was a finding of a direct agreement to fix prices or otherwise restrain competition. There seems to have been ample evidence for the reviewing court to sustain the Commission's finding of direct conspiracy, under the substantial evidence rule, without considering the presence of the delivered price system. Therefore these cases do not deserve to (although they may) be considered as precedents for the "conscious parellelism of action" theory.

Finally, the Crown case ${ }^{103}$ directly extends the implied conspiracy doctrine further than any previous case, and to a point very little short of the degree herein referred to as "conscious parallelism of action." The evidence which the Commission found to show a conspiracy to fix prices and restrain competition, and which the Fourth Circuit Court of Appeals held sufficient to sustain such finding, consisted of, in addition to use of a freight equalization system ${ }^{104}$ and uniformity of

${ }^{88}$ Milk \& Ice Cream Can Institute v. Federal Trade Comm'n, 152 F. 2 d 478 (C. C. A. 7th 1946).

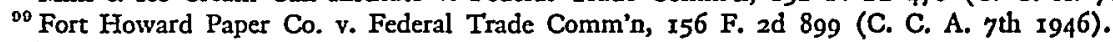

${ }^{100}$ Triangle Conduit \& Cable Co. v. Federal Trade Comm'n, 168 F. 2d 175 (C. C. A. 7th 1948), aff'd per curiam sub nom. Clayton Mark \& Co. v. Federal Trade Comm'n, 336 U. S. 956 (1949).

${ }^{102}$ Allied Paper Mills v. Federal Trade Comm'n, 168 F. 2d 600 (C. C. A. 7th 1948), cert. denied, 336 U. S. 918 (1949).

${ }^{102}$ Id. at 607 . (Italics supplied.)

${ }^{103}$ This case arose out of a proceeding by the Commission (Docket No. 4602) against 13 manufacturers of crowns (metal caps for beer and soft drink bottles) and their trade association. The complaint and the cease and desist order charged and prohibited only a conspiracy to fix prices and restrain competition, not containing any Count II, such as in the Rigid Steel Condrit case, raising the issue of individual delivered price selling as an unfair method of compctition. The trial examiner had recommended dismissal of the complaint, having felt that the evidence showed no unlawful activities on the part of either the trade association or the member companies.

${ }^{10}$ 'Each manufacturer sold f.o.b. its own factory and announced that it would "equalize freight," i.e., lower its price sufficiently to compensate for the freight advantage of the competitor closest to the 
prices, ${ }^{105}$ the following: (I) Standardization through the trade association of colors and designs for "stock crowns" (crowns for soft drinks which show only the name of the drink and not the name of the bottler) ${ }^{100}$ (2) discussion at a trade association meeting in 1928 of a standard sales contract the provisions of which, although the contract was never adopted and used, were followed in large part by the various manufacturers; ${ }^{107}$ and (3) a series of patent license agreements between the largest manufacturer in the industry and other manufacturers, which agreements required the licensees not to sell at prices lower than those of the licensor, and in connection therewith the furnishing of price information by the licensor to the other manufacturers (this price maintenance provision of the patent licenses was eliminated prior to institution of the proceedings by the Commission).

The significance of the Crown case in relation to "conscious parallelism of action" is twofold:

First, it demonstrates with added emphasis the attitude of reviewing courts that the inferring by the Commission of a conspiracy must not be set aside except under the most extreme circumstances. In this case there was less substantial evidence to support the inference than in any previous delivered price case. Also, there was no evidence whatsoever that an improper purpose underlay any of the five practices relied on, and there was some evidence of a. "normal business reason" for each. However, the court said, "It is argued that all this is the result of the free play of economic forces, but the Commission did not think so; and this is just the sort of question that Congress intended the Commission to decide"108 (followed by a quotation from the Cement opinion).

Second, it demonstrates the power of the Commission to infer a conspiracy in virtually any industry where there is delivered price selling. Where delivered price selling is found, there is ordinarily a homogeneous or standardized product and there is ordinarily a high degree of price uniformity. These are the elements men-

customer's delivery point, if any. There was no evidence of any kind in the record of any agreement to establish or continue this method of selling, an important difference from the Cement case.

${ }_{105}$ There was some evidence in the record that crown prices had been kept down in recent years below what they otherwise might have been by pressure from bottlers of 5 -cent soft drinks who desired to maintain the 5-cent selling price in the face of rising costs. The court obviously was impressed not only by the uniformity of prices among the respondents but also by the price rigidity-no change in prices from late 1938 until the closing of the record in 1947 . In stressing this point the court did not mention the effect of OPA during five years of this period nor the 5-cent drink factor. Examination of the opinion as a whole leaves a doubt that absence of this price rigidity would have caused a different holding by the court.

${ }_{100}$ The trial examiner found that such standardization was for the convenience of bottlers and users of carbonated beverages and had nothing whatsoever to do with price fixing The findings of fact of the Commission, without reciting any evidence that the standardization program was for the purpose of price fixing, merely recite that buyers of stock crowns could not obtain any advantage in price by reason of competition among the manufacturers in the realm of design, combinations of colors or appearance, and the Commissioners inferred an understanding and combination to fix prices.

${ }^{107}$ The draft of the contract embodied practices in effect prior to that time, so the fact that they were thereafter followed does not indicate any change of business methods toward new and greater uniformity.

${ }_{208} 176$ F. 2d 974, $98 \mathrm{I}$. 
tioned by the court in its summarization. ${ }^{109}$ Until now, these three circumstances in conjunction have not been generally regarded as necessarily indicating a conspiracy. Yet under this case the Federal Trade Commission seems to have discretion so to find. Here is new support for Commissioner Mason's vision of thousands of potential respondents. ${ }^{110}$

The implication from this group of recent cases, together with the failure of Congress to agree on any delivered price legislation during the past year, is that for the immediate future this portion of the body of antitrust law will be shaped mainly by the policy makers at the Federal Trade Commission.

It is not improbable that the Commission will jettison the phrase "conscious parallelism of action" while retaining the principle.

This change of approach is foreshadowed by numerous official statements by the Commission, and semi-official statements by members of the Commission's staff, during the year following the coining of the phrase. ${ }^{111}$ As has been noted, the policy statement itself paves the way for substitution of the word "conspiracy." Possibly some softer sounding word such as "understanding" may come into more common use. ${ }^{112}$ The phrase "tacit conspiracy" has been used by Mr. Corwin D. Edwards, Director of the Bureau of Industrial Economics of the Federal Trade Commission, in an exposition ${ }^{113}$ on this subject which, as a possible guide to the current and future attitude of the Commission, deserves the most careful consideration and evaluation.

\section{IV}

\section{Problem Created By Doctrine}

Although "conscious parallelism of action" has not yet achieved the status of a legal principle, the trend in that direction has reached a point which requires general awareness of its implications. Such awareness should bring an overwhelming demand for abandonment of this theory.

Culmination of the trend toward acceptance of the "conscious parallelism of action" theory means mandatory uniform f.o.b. mill pricing just as surely as does culmination of the trend embodied in the recent series of cases ${ }^{114}$ under the Robinson-Patman Act dealing with delivered pricing.

Anything other than uniform fo.b. mill pricing requires that sellers in most industries have the right to adjust their prices by amounts exactly necessary to

${ }^{109}$ Id. at 979. Nor are the other two elements which are found here uncommon circumstances.

${ }^{210}$ Hearings, supra note 6 , at 66-72.

111 See note 7 supra.

${ }^{112}$ See par. 13 of Commission's findings in the Crown case, supra note 87 , at 976 .

${ }^{123}$ Edwards, supra note $2 \mathrm{I}$.

${ }^{124}$ Federal Trade Comm'n v. Morton Salt Co., 334 U. S. 37 (1948); Federal Trade Comm'n v. Cement Institute, 333 U. S. 683 (1948); Corn Products Refining Co. v. Federal Trade Comm'n, 324 U. S. 726 (1945); Federal Trade Comm'n v. A. E. Staley Mfg. Co., 324 U. S. 746 (r945); Standard Oil Co. v. Federal Trade Comm'n, 173 F. 2 d 210 (C. C. A. 7th 1949); see Corn Products Refining Co., FTC Docket No. 5502 (opinion of Commissioner Mason concurring in order denying motion to dismiss complaint dated July I2, 1949). 
overcome the freight advantage of competitors. ${ }^{115}$ This may be done by what is broadly called "freight absorption" or may take some other form. Inevitably it must be systematic, and ordinarily it will result in substantial identity of published (list) prices at any particular delivery point. As a practical business matter, ${ }^{116}$ there is no middle ground between uniform f.o.b. mill pricing and "systematically matching delivered price quotations" as that phrase is used by the Federal Trade Commission, ${ }^{117}$ except perhaps in industries with non-homogeneous products.

Such "matching" cannot be avoided. If A Company wants to do business in the territory adjacent to B Company's plant, A Company must announce to these prospective customers (or instruct its salesmen) that it will reduce its delivered prices by the amount of B Company's freight advantage. ${ }^{118}$ Thus A is "matching" B's prices. Nor is there anything reciprocal-in any improper sense-in this situation. $B$ is powerless to prevent $A$ from invading B's territory by such freight absorption, and $A$ powerless to prevent $B$ from doing the same thing. The only thing B could do would be to lower its f.o.b. mill price to a point which would require $A$ to absorb so much freight as to make it unprofitable to do so. In actual situations this is ordinarily not feasible. In most, if not all, industries where delivered price methods are used, the freight between plants is a relatively small portion of the total price, or there is some other precluding circumstance, such as a constant shifting of predominant demand areas, seasonally or otherwise.

It is not necessary to debate here the economic merits of uniform f.o.b. mill selling. It is assumed that mandatory uniform f.o.b. mill pricing is not desirable as a matter of public policy. This assumption is supported by Congressional sentiment ${ }^{119}$ displayed since the Cement decision.

Continuously since that opinion was announced on April 26, 1948, Congress has been wrestling with the problem of "re-legalizing" geographical competition

${ }^{115}$ This discussion relates, of course, to the considerable number of commodities generally referred to as homogeneous or standardized.

${ }_{110}$ Any doubts as to the utter impracticability of non-systematic freight absorption should be dispelled by study of the testimony of a great many witnesses from a considerable number of industries before the Trade Policies Subcommittee of the Senate Committee on Interstate and Foreign Commerce pursuant to S. Res. 24I, 8oth Cong., 2d Sess. (1948).

${ }_{117}$ The phrase derives its connotation in large part from its use in the Rigid Steel Conduit case. See note 40 supra. The Commission has consistently striven to ignore the significance of non-identity of actual off-list selling prices as contrasted to identity of published prices. It has sometimes asserted that off-list selling merely constitutes instances of failure of a conspiracy to function.

In our opinion too much emphasis has been placed on sealed bids to Government agencies. See Justice Burton's dissenting opinion in the Cement case, supra note 15 , at 736 n. 8 . Too little credence has been given by the Commission to contentions of respondents that they have not bid at less than published prices because of a fear that such action would lead their commercial customers to press for similar price reductions. A recent example of the validity of this position is found in a news story to the effect that lower prices bid to the Air Force on serge cloth had aroused hopes of men's clothing . manufacturers that they could obtain worsted at lower prices. N. Y. Journal of Commerce, July 15, 1949, p. 13, col. 3 .

${ }_{118}$ Any lesser reduction presumably would not enable A Company to make any sales. A greater rcduction would raise a Robinson-Patman Act problem.

${ }^{120}$ Sen. Doc. No. 27, 81st Cong., Ist Sess. 64 (1949); H. R. Repr. No. 869, 81st Cong., Ist Sess. 2 (1949). 
through delivered price selling. Attention has been focused, however, on amending the Robinson-Patman Act, and no real effort has been made to deal with the equally serious problem of the "conscious parallelism of action" theory under Section 5 of the Federal Trade Commission Act.

True, S. $236^{120}$ made a stab at tackling this problem, and S. $1008^{121}$ also proposes an amendment of Section 5. But it is highly doubtful that either bill, if enacted, could prevent the Commission, as long as the present attitude continues, from applying the "conscious parallelism of action" theory.

Therefore, since "conscious parallelism of action" will ultimately require uniform f.o.b. mill pricing, and since mandatory uniform f.o.b. mill pricing is not desired, the crucial question is how to put an end to the "conscious parallelism of action" theory. ${ }^{122}$ The problem is how to kill the weed itself, making sure that it does not continue to flourish under a new name.

\section{$\mathrm{V}$}

\section{The Solution of the Problem}

This problem may be dealt with by the Congress, by the courts, and by the Commission itself. Under the circumstances, positive action by all three seems called for.

\section{A. The Congress}

It would be unfortunate should the Congress be forced to deal alone with this whole problem. In addition to the practical difficulty of overcoming the uncomprehending political objections to "weakening the antitrust laws," the obstacle of legislative draftsmanship seems to be considerable.

It would be a ticklish undertaking indeed to attempt to draft legislation which would prevent a stubborn Commission and stubborn courts from following the lure of "conscious parallelism of action," without at the same time imposing unwarranted restrictions upon the power to find conspiracies from substantial, though circumstantial, evidence. It would not be adequate merely to provide, along the lines of S. 236, that common use of a delivered price system shall not alone be considered proof of a conspiracy, but that this fact may be considered as evidence of conspiracy in conjunction with other evidence. The effect of such a statute could too easily be avoided by more or less evidence of other common but non-conspiratorial business practices. ${ }^{123}$

The role of Congress probably stops at merely making clear the Congressional policy in general terms. The preamble to S. $236^{124}$ is one way this might be done.

120 8Ist Cong., Ist Sess. (1949).

121 8Ist Cong., Ist Sess. (as passed by the Senate, 1949).

122 Amendment of the Robinson-Patman Act to forestall mandatory f.o.b. mill pricing via that route is equally necessary, of course.

${ }^{123}$ See discussion of the Crown case, sttpra, pp. 250-252.

126 "Section $\mathrm{I}$. In order to permit the treatment of transportation costs in interstate commerce to contribute to the promotion of competition in American industry among all sellers for the business of all 
Or the policy declaration might be stronger, amounting to specific enactment of the rule of reason. The Commission and the courts, it is hoped, would apply that policy in individual case situations.

Because the trend toward "conscious parallelism of action" has gone so far in decisions of the Commission and reviewing courts, a Congressional declaration of policy is probably essential. Congress should also play a watchdog role to see that its policy is being followed. If necessary thereafter, more detailed substantive legislation should be attempted.

\section{B. The Federal Trade Commission}

The problem can best be solved by reorientation within the Federal Trade Commission. This involves several steps: (I) abandonment of the views that delivered price selling is economically bad and inherently collusive; (2) abandonment of the "conscious parallelism of action" theory; and (3) adoption of a "rule of reason" approach to cases involving industry-wide delivered price selling.

The phrase "rule of reason" may not be an altogether happy one in this connection but is used here for want of a better. This phrase, of course, connotes the existence of a restraint on trade or competition and the determination whether such restraint is unreasonable. ${ }^{125}$ In delivered price cases the basic question is whether there is any restraint. As to implied conspiracies, the term "rule of reason," as here used, means requiring more proof than coincidental use of ordinary, reasonable (with reference to self-interest) business practices, looking under the surface to weigh special circumstances of the industry involved, and searching for rather than assuming the facts as to injury to the public. ${ }^{126}$ Further, there should be

buyers; to safeguard and secure to American workers continued employment in the areas in which they now make their homes; to promote the full development of our national resources, particularly in presently sparsely settled areas, and effectively to utilize the vast transportation systems of the United States, it is the policy of the Federal Government-

"(a) to develop a consistent and coordinated program of promoting competition, as affected by transportation costs, in interstate commerce, by the Federal Trade Commission, the Civil Aeronautics Board, the Post Office Department, and the Interstate Commerce Commission;

"(b) to foster competitive private enterprise by the treatment of transportation costs in interstate commerce so that access to distant markets may be available, when economically feasible, to any competing seller;

"(c) to encourage the Interstate Commerce Commission to continue and extend the policy of promoting regional and sectional competition by the establishment of appropriate transportation rates where required and in the best interests of the national economy;

"(d) to clarify the practice by the Federal Trade Commission which will permit all competing sellers to have access to distant markets by directing the treatment of transportation costs in interstate commerce to promote competition;

"(e) to prohibit the requiring of the sale of products at f.o.b. factory or mill prices, where buyer and seller do not choose to transact business on such terms; and

"( $f$ ) to insure to all consumers the advantages of active competition in distribution of all products."

125 United States v. American Tobacco Co., 221 U. S. 106, x79-80 (I9II).

${ }^{120}$ General statements by the Commissioners to the Trade Policies Subcommittee of the Senate Committee on Interstate and Foreign Commerce, created pursuant to S. Res. 24I, 8oth Cong., $2 d$ Sess. (1948), appear to indicate more of such searching than is indicated by analysis of recent decisions of the Commission. 
consideration of the positive, not merely the negative, effects of complying with the Commission's cease and desist orders. ${ }^{127}$

It has frequently been said that the courts are not equipped to make the economic determinations required in applying the rule of reason. ${ }^{128}$ But the principal reason for the creation of the Federal Trade Commission was to have an agency so equipped. If the Commission refuses to exercise this responsibility, and applies to Section 5 cases the per se doctrines of Sherman Act cases, then consideration should be given to vesting sole jurisdiction of conspiracy cases in the district courts $^{129}$ in order to give respondents the protection of jury trial, rules of evidence, proof by preponderance of the evidence, etc.

The Federal Trade Commissioners should ponder on the words of Justice Jackson in his concurring opinion in the Krulewitch case. ${ }^{\mathbf{1 3 0}}$ These thought-provoking words apply equally to findings of a conspiracy and findings of participation by "fringe" conspirators. ${ }^{131}$

Our experience with conspiracy cases in the antitrust field has convinced us that unlawful collusion is not nearly so difficult to prove as is popularly supposed. ${ }^{\mathbf{1 3 2}}$ Few businessmen are either willing liars or adroit ones. Where collusion exists a reasonably competent trial attorney, having available the fruits of a reasonably efficient field investigation, should have no great difficulty in obtaining enough admissions by examining the businessmen involved, and their correspondence, to establish the existence of the conspiracy either by direct evidence or by circumstantial evidence so strong as to be almost the equivalent.

The present difficulty with the position of the Commission in this regard is that it wants to be able to apply the "conscious parallelism of action" theory where there is no conspiracy. The difficulty results from the fact that the Commission has been controlled by economic views inconsistent with the policies of Congress as to price leadership and competition on a geographic basis.

Hope for adoption of the "rule of reason" approach by the Commission seems to rest mainly on the views of the new Commissioners. The hope cannot be realized unless the new members of the Commission have or acquire sufficient background in the field of trade regulation to grasp the problem involved and sufficient force of personality not to be subservient to the lawyers and economists on their staff.

${ }^{127}$ See Clark, The Law and Economics of Basing Points: Appraisal and Proposals, 39 AM. EcoN. REv. 430, 446-447 (1949); cf. Oppenheim, Should the Robinson-Patman Act be Amended? in CCH, Robinson-Patman Act Symposium, Section on Food, Drug and Cosmettc Law of the New York State Bar Ass'N r4I (1948).

${ }^{128}$ Cf. Federal Trade Comm'n v. Keppel \& Bros., 291 U. S. 304, 314 (1934).

${ }^{129}$ Statement on S. Ioo8 submitted to the Subcommittee of Senate Judiciary Committee by Raymond S. Smethurst, Counsel for NAM, in Hearings, supra note 36 , at 120 .

${ }^{130}$ Krulewitch v. United States, 336 U. S. 440, 445 (1949).

${ }^{131}$ Compare the differing views in the Cement case, of the Supreme Court (333 U. S. at 7x9-720) and the Court of Appeals for the Seventh Circuit (I57 F. 2d at 55I-555). See also Justice Burton's dissenting opinion ( 333 U. S. at 736-737).

${ }^{122}$ See statement of John D. Clark, in Hearings before the Subcommittee on Study of Monopoly Power of the House Iudiciary Committee, 81st Cong., 2d Sess. (1949). 


\section{The Courts}

The Supreme Court and the United States Courts of Appeal can make their contribution by performing their function of judicial review in the real sense intended by Congress. ${ }^{133}$ A conscientious court can, without too much difficulty, require the Commission to depend on factually supported conclusions instead of mere theories. ${ }^{134}$

Also, the ever-present problem of careful opinion writing is particularly aggravated in delivered price cases. The Supreme Court's Cement opinion has been severely criticized by various members of Congress. ${ }^{135}$ The group of delivered price-conspiracy opinions of the Seventh Circuit Court of Appeals ${ }^{136}$ obviously shows need for more understanding of the underlying situation.

Awareness on the part of these courts of the basic Congressional policy toward the bona fide delivered price meeting of competition, and insistence that Federal Trade Commission personnel do not substitute therefor their own theories, would relieve Congress of the difficult task of legislating specifically against "conscious parallelism of action." The problem is of such magnitude that if the Commission and the courts do not solve it in a reasonable manner, Congress must sooner or later become convinced of the necessity for substantive legislation.

${ }^{233}$ See the dissenting opinion of Justice Jackson in Federal Trade Comm'n v. Morton Salt Co., 334 U. S. 37,58 (1948).

${ }^{234}$ The most recent example is Tag Mfrs. Institute v. Federal Trade Comm'n, I74 F. 2d 452 (C. C. A. Ist 1949).

${ }^{135} 95$ Cong. Rec. $7 \times 57-7158$ (May 3I, 1949); id. at 9164, 9168 (July 6, I949); id. at 9233-9234, 9237 (July 7, I949); id. at r1554 (Aug. I2, I949); H. R. Rep. No. 869, 81st Cong., Ist Sess. I (1949); Sen. Doc. No. 27, 81st Cong., Ist Sess. 5 (1949).

136 See notes 96-I01 stipra. 